\title{
Social Security in the 21st Century
}

The 2000 Leon and Josephine Winkelman Lecture University of Michigan School of Social Work

March 13, 2000

\section{Edward M. Gramlich, Ph.D.}

Board of Governors, Federal Reserve System 
I am very happy to return to Ann Arbor to give the Winkelman Lecture. The lecture series was established for the discussion of social and biological issues in the field of gerontology. It takes a bit of a stretch to ask an economist to comment on any issues in the field of gerontology, and I am deeply honored to be invited. My topic today will be social security, the federal government's largest and most popular social program and the one with the clearest impact on the financial well-being of older Americans.

Going beyond their mutual contact with gerontology, there is a connection between the Winkelman family and social security that I think most people don't know about. Stanley Winkelman, one of the founders and benefactors of this series and also a long-time and esteemed philanthropist in this area, died last August. He was distantly related to Wilbur Cohen, who was on the faculty of the School of Social Work but, more relevantly, was also one of the drafters of the original Social Security Act. It then seems very fitting to give this first Winkelman Lecture after Stanley's death on social security, a topic that he would have cared deeply about and a program that his relative helped to create.

In fiscal year 1999, social security paid $\$ 387$ billion in benefits to 45 million people. These benefits make up roughly 40 percent of the income received by aged families and more than 80 percent of the income received by the poorest aged families. Social security has not eliminated aged poverty, but it has been largely responsible for a reduction in the aged poverty rate from 35 percent back in 1959 to 11 percent today. Because of its support to aged people of all incomes, poll after poll has indicated social security's unique political popularity. Politicians treat social security as the "third rail" of American politics: "Touch it and you die."

The original Social Security Act was passed back in 1935, the most significant and lasting domestic policy achievement of Franklin Roosevelt's New Deal. The program's history in the 20th century was one of steady growth. The combined employer-employee payroll tax to finance the program started at 2 percent in 1937 and rose gradually through the years to 12.4 percent by the close of the century. This tax was assessed on the first $\$ 3,000$ of wages in 1937 and is assessed on the first \$76,200 today. Coverage was sporadic at first, but the program now covers more than 96 percent of the workforce. Normal program benefits have also risen through time for covered workers. A disability insurance program was added to the normal retirement benefits in 1954, and benefits were automatically indexed for inflation beginning in 1975.

But although growth was the watchword in the 20th century, many commentators now predict a slowdown in program growth. The program is now mature, in the sense that coverage is nearly universal and benefits automatically rise at roughly the same rate as overall wages and salaries. But unlike the situation for most of the 20th century, as we move to the 21st century the United States is looking at a massive aging of its population. Whereas 16 workers paid taxes to finance benefits back in 1950, the number has dropped to 3.4 now and is slated to drop to 2 in another three decades. The consequence is that it will take an immediate payroll tax increase, now estimated at 2.6 percent (bringing the total to 15 percent), just to pay for the present benefit system over the standard 75-year forecasting period, and a greater tax increase if this period is extended even a few years. Yet unlike in the 20th century, when such a payroll tax increase would have been the normal response to impending financial problems, almost all politicians of either party now oppose further payroll tax increases, and some advocate reductions.

What worked politically in the 20th century may not work in the 21st century.

In this talk I will try to assess the economic and political outlook for social security, the signature social program of the 20th century, in the 21st century. I will review the objectives that I believe America should keep front and center in dealing with social security, and some of the problems now facing the system. I will comment on the experience of other countries: Many adopted their own social security programs about the time that the United States did, and many face similar problems with their own systems. Then I will promote my own magic bullet of social security reform - whatever else they do, reforms should try to raise national saving, in effect prefunding future benefit payments. 


\section{Objectives and Problems}

\section{Social Protections}

The fundamental objective in dealing with social security should be to preserve its massive system of social protections. The program contains some internal redistribution, in the sense that returns on contributed payroll taxes are higher for low-wage workers than for high-wage workers. These higher returns, reflected in relatively higher benefit payments for lower-wage retirees, largely explain why the program has been responsible for so much reduction of poverty among the aged and partly explain why social security accounts for such a high share of the retirement income received by lower income retirees. In addition, the disability program gives workers and their families protection against the financial consequences of workplace disabilities. Family members of workers who die prematurely receive early survivor's insurance. Social security benefits are also real annuities, which means that payments go on as long as retirees live, with added protection for surviving spouses. Not only that, but these benefits are automatically protected from inflation.

Social security is one of the few pension programs in America that has this feature. All of these social protections have existed for some time now, so long that they may be taken for granted. Preserving them should be the first order of business.

Although preserving the main social protections is fundamental, benefits could be improved or modified. One obvious change is in coverage. Program coverage is now nearly universal, except for a share of state and local workers and some other workers in sectors that will eventually be fully covered. A standard suggestion for program reform is to move toward complete coverage, eliminating some minor inequities in the process. A second suggestion involves poverty reduction.

Because of the way benefits for surviving spouses are computed, America still has high poverty rates among aged widows, rates that are much higher than those in other developed countries. There are relatively simple and cheap ways to change the computation of survivor benefits to cut into this high rate of aged widow poverty.

Two other problems with the benefit system receive most of the discussion. One involves the so-called normal retirement age for the computation of benefits. The social security system computes benefits through a formula based on the payroll tax contributions that workers have paid into the trust fund. This computation leads to a standard benefit received at age 65, the normal retirement age now, as indeed it was back in 1935 when the program was established. But, of course, workers live much longer now than they did then, and the gradual lengthening of retirees' life spans is the major cause of the financial problems now facing the system.

Workers can retire and collect benefits as early as age 62, taking an actuarial reduction in benefits if they do so. They can also gain more benefits from the delayed retirement credit if they work past age 65 . Retirees who work are also subject to social security's earnings test, a measure that has never made much sense in the logic of the social security program, and that may not be with us much longer. Previous legislation has the normal retirement age rising in steps to age 67 over the next two decades. Many have proposed going beyond this legislation and tying the normal retirement age to life expectancy, computing benefit payments on the assumption that different cohorts of workers could be spending a constant share of their expected lifetimes in working and retirement years.

Proposals to raise the normal retirement age are hugely controversial, perhaps because they are generally misunderstood. What is misunderstood is the fact that, if workers are still permitted to retire and collect benefits at age 62, the rising normal retirement age really means only a slight cut in benefits for workers retiring at any fixed age. It does not mean that these workers would have to work until these older ages. This slight cut in benefits may or may not be a good idea - there are powerful arguments for making some cuts in benefits, and no cut would be loved by everybody. At the same time, it is legitimate to ask whether benefits should be cut in this way or disproportionately for higher-income individuals who may not have worked in physically arduous careers. 
The second issue that commonly arises on the benefit side reflects the fact that social security is largely a social protection program, not a full program for retirement benefits. Social security today provides most retirement income for low-wage retirees but a lesser share as we move up the income scale. The idea is that higher-wage retirees should, if they wish to continue their pre-retirement living standards, supplement social security with private pensions and their own saving. Unfortunately, many do not. Roughly 40 percent of households in the $\$ 25,000$ to $\$ 50,000$ income class do not have pensions, and roughly 30 percent of households with incomes above $\$ 50,000$ do not have pensions. These workers at least ought to be thoroughly warned about the impending decline in their standard of living, perhaps induced to save more by tax incentives, and perhaps even required to save more. I'll return to this saving issue below.

\section{Actuarial Balance}

From its inception, social security has been set up in a very responsible way financially. Employer and employee taxes, along with a small amount of revenue from the income taxation of benefits, go into a trust fund that is used to pay social security benefits. For the first 40 years of its history, this trust fund ran on a pay-as-you-go basis. Current payroll tax revenues were used to pay benefits, with little system for accumulating assets. Program changes made in the 1980s moved slightly toward the prefunding of benefits. The coming demographic shift was well-recognized in the 1980s, and changes made then raised payroll taxes ahead of benefit payments, with the consequence that the social security trust fund is now running a cash surplus of about $\$ 150$ billion per year, rising by about $\$ 15$ billion a year for the next few years. This surplus is invested in government securities, with social security credited for all interest on these securities. Political talk about stealing social security benefits to finance the rest of government is fundamentally inaccurate. No social security funds are being stolen; the fund is making loans and getting full interest on these loans. In this respect, the social security fund is behaving just like any other prefunded pension plan that invests in Treasury securities.

Although the system's financial situation appears healthy, as we look ahead things change. The system builds in a financial exercise in which the trustees - four cabinet officers and two outside members - make actuarial forecasts 75 years into the future. Seventy-five years is obviously a long time, and these forecasts should by no means be viewed as precise predictions. At the same time, given the relatively predictable future demographics of the country - people live reasonably predictable lifetimes, and the future size of the labor force can be reasonably well forecast - these forecasts are useful indicators of future imbalances.

Right now the forecasts indicate that the system will continue to build its assets for another 20 years and then run these assets down fairly sharply as the huge baby boom population moves into retirement. System assets are forecast to be exhausted in roughly 2035, and it would take an immediate 2.6 percent increase in the combined employer-employee payroll tax rate to extend the system's assets for the 75-year forecasting period. Given the aging of the population, the asset shortfall gets much more dramatic beyond 75 years - the payroll tax increase necessary to finance future benefits in perpetuity was most recently estimated at 7.7 percent.

Viewed as a share of the overall economy, if no changes are made, retirement and disability benefits are expected to rise from 4.3 percent of total national output today to 7.3 percent of total output by the end of the 75 -year period, and to higher levels further in the future. Perhaps more significantly, when combined with a similar growth in Medicare, these types of entitlement spending roughly double as a share of federal revenues in the course of three decades, crowding out other types of government spending or requiring new federal tax increases. These indicators suggest that some changes should be made on the benefits side.

There are many such changes. In this talk I will not get into a full discussion of options. But if changes are to be made on the benefit side, hence both improving the trust fund finances and limiting the share of total output and federal revenues used for entitlement spending, it is far, far better to make the changes early rather than late. These entitlement programs are retirement programs, which means that workers make their retirement plans based on an assumption of benefits that will be available. It is widely viewed as unfair to change benefits for present retirees who have already quit their main job, and in fact important benefit cuts for retirees have never been enacted in the 
whole 60-year history of social security. It is nearly as unfair to cut the benefits of workers nearing retirement ages, for precisely the same reason. Hence, if benefits are to be cut enough to matter, they should be cut in a very gradual way, beginning early, and with the largest cuts in store for the youngest workers for whom retirement is a long way away and retirement planning is still very flexible. In this sense, these future dates can be very misleading.

While the system might reasonably expect enough future revenues to pay the present schedule of benefits until 2035, sensible changes in benefits schedules should be enacted well before 2035. Very soon, in fact.

\section{Rates of Returns}

Since social security benefit payments are based on workers' previous payroll tax contributions, it is possible to compute implicit internal rates of return on these contributions. Many years ago, the economist Paul Samuelson established that the long-run equilibrium real return on a pay-as-you-go pension fund of this sort would be equal to the trend rate of growth of real wages plus the trend rate of growth of the labor force, roughly 1 percent according to present assumptions.

But these are equilibrium returns. As the system builds to maturity, returns can be higher. For example, workers born in the 19th century and retiring in the early years of social security got much higher returns - they received full benefits but with contributions paid only from 1937 on.

Workers born early in the 20th century are getting reasonable returns. For example, single workers born in 1920, earning average amounts of wage income and living normal life spans, are receiving a real return on their and their employer's social security contributions of nearly 3 percent, roughly what would have been available in the bond market over this period. In addition, because of the internal redistribution in the system, lower-wage workers of any birth cohort get higher-than-average returns. Workers of any birth cohort who die early get lower-than-average returns. These differences are conscious and, in fact, implicit in the social insurance structure of the program.

But now that the program is maturing, the inalterable mathematical logic of Samuelson's proof is coming true, and implicit rates of return are dropping toward 1 percent. Whereas average income and life span workers born in 1920 received real returns essentially equal to those on government bonds, average income and life span workers born now are expected to receive real returns of about 1 percent, much below the likely real return on bonds. Highincome workers born now are even likely to get negative returns.

Nothing can be done about these basic profiles. The underlying math is incontrovertible. Moreover, social security did pay out high financial returns to earlier birth cohorts, effectively laying a further tax on younger and as yet unborn workers. These younger workers may regret both the underlying math and this tax, but they cannot change either. And in terms of underlying social equity, these younger workers should remember that they did not have to live through two world wars and a depression, and that they are benefiting from the rising productivity and living standards of the American economy. But it is still true that if internal rates of return continue downward, the basic political popularity of social security could at some point be threatened.

This is why prefunding, or new national saving, is so important. Any new funds devoted to the retirement system can in effect be invested in new capital and can pay at least the marginal real return on such funds, now roughly 4 percent if funds are invested in bonds and perhaps even more if some funds are invested in equities. Moreover, new saving represents a way to place some of the costs of future benefits on those now in the workforce, who are already likely to receive higher rates of return than will future cohorts. While returns are inevitably dropping within the present system, new saving should continue to pay high returns at the margin, and it represents a fair way to pay for future benefit costs. 


\section{Here and Abroad}

Before trying to develop solutions to these impending problems, we should look abroad. As it happens, populations are aging around the world, putting much pressure on foreign social security systems. If anything, problems seem worse for most foreign developed country systems than they do here.

The basic math in understanding pension plans focuses on birth and death rates. If women have on average more than 2.1 babies in their reproductive years, populations expand and have a relatively high share of young people. If women have on average less than 2.1 babies, populations contract and have a relatively high share of old people. Then, as mortality declines, the share of old people rises again, adding to the phenomenon known as the aging of the population.

Around the world both fertility and mortality rates are dropping in country after country. Fertility rates are already well below 2.1 in most developed countries and approaching 2.1 in most developing countries. Life spans are already quite long in most developed countries and are rising in most developing countries. The full social implications of these trends are overwhelmingly positive. The drop in fertility rates lowers population growth rates and takes pressure off the world's resources, and the drop in death rates implies a generally healthier and more productive workforce, with people permitted to live into their retirement years to enjoy the fruits of their labors. But while these trends are laudable and even exciting, they do imply an overall aging of the world's population, and they do put extra pressure on all national retirement systems that do not prefund benefits.

As an indication of these pressures, the 22 Organization for Economic Cooperation and Development (OECD) countries with the most-developed economies and social security systems had 18 percent of their population over age 60 in 1990, with that share expected to grow to 31 percent by 2030. The share of population over age 75, the population group for which the social cost of care is much higher, is expected to grow from 5 percent now to more than 10 percent by 2030. Similar trends are evident in the transitional socialist countries of Eastern Europe and in China, Latin America, Asia, and even Africa, though the less-developed regions start with smaller shares of their populations in the higher age groups.

The result of this aging of the population, around the world as in the United States, is a growing share of the economy devoted to paying for public pension spending. The forecast share rises to more than 15 percent of total output by 2030 for the OECD countries (more than double the ratio for the United States), to nearly 15 percent for the transitional socialist countries and China, and to nearly 10 percent for Latin America and the rest of Asia.

Most countries have yet to deal with their looming pension system problems, but a few have. The United Kingdom, Australia, and several Latin American countries, most notably Chile, have all gone to systems that feature basic flat benefits and then prefunded individual accounts on top of that. What usually gets attention is the fact that these countries have partly privatized their pension systems, but I would like to focus on the fact that these countries have partly prefunded their systems. In so doing, they have directly provided for some of their future pension costs. They may have also generally raised their national saving, realizing a high marginal rate of return, and they could reap the benefits of a higher general standard of living down the road. While the United States begins with lower future financial costs of its aging society than is the case in most other developed countries, and may not want to replicate these other pension plans, it could well consider moving in the direction of prefunding benefit payments.

\section{Solutions}

Many solutions have been proposed to this interrelated set of social security problems. To keep the discussion manageable, I will focus on four basic approaches - one based on the normal 20th-century response, two representing present political opinion in Washington, and one that I proposed earlier in the report of the 1994-96 Social Security Advisory Council. Though, as I said above, one can make very good arguments for at least a slow trimming of the growth of benefits over time, the proposals are very much alike in that each preserves in essential 
form the present system of benefits. Each also preserves the present set of social protections, the first objective I described. Further, each tries to restore the long-run actuarial solvency of the social security trust fund. The proposals differ in their economic dimensions - whether they prefund some future benefit costs, whether they raise national saving and take advantage of the higher marginal return on this new saving, and whether they increase payroll tax rates.

The standard 20th-century solution to the financial problems posed by an aging society was to raise payroll taxes. Were this to be done now, these payroll taxes would be invested in government securities and would yield interest down the road. The combination of future taxes and future interest returns would pay for the rising future benefit costs. Under present actuarial estimates, an immediate 2.6 percent increase in the combined payroll tax rate is necessary to finance the present benefit schedule for the next 75 years; an immediate 7.7 percent increase is necessary to finance the benefit schedule in perpetuity.

Although this approach is a simple and straightforward way to lower consumption and raise national saving, it is not altogether appealing. For economists, it introduces the issue of tax-rate distortions. As marginal tax rates increase, incentives for people to work and be productive could be reduced. Social security taxes may not operate like other taxes in this regard, because people do get the money back, albeit with some redistribution. Moreover, while going from 12.4 percent to 15 percent may not seem terribly significant, we must remember that the overall ratio of federal taxes to national output is about 20 percent now, and this increase will come on top of these other taxes. The cost of tax distortions is usually felt to depend on the square of marginal tax rates, and 22.6 percent squared is one-fourth more than 20 percent squared. Moreover, tax rates cannot be raised forever. At some point, every country with an aging population has to get off what we might call the tax and spend treadmill. Indeed, the main reason that impending tax burdens look less onerous for the United States than for other countries is that in the past the United States has held the line better against tax and benefit increases. Finally, for what it is worth, tax increases are a political anathema: At this point, no politician of either party would give this approach even passing consideration.

In the set of recommendations accompanying the report of the 1994-96 Advisory Council, I tried to come up with an alternative way to raise national saving. Instead of raising payroll tax rates, I suggested what I thought might be a more popular approach of mandatory individual accounts held on top of social security. Since individuals would own these accounts, they might not think of them as tax increases. Moreover, individuals would be free to invest these funds in a constrained set of stock and bond index funds, much as happens today in employer-controlled defined-contribution private pension accounts. Even if the investments were confined to bonds, their return would be much higher than present payroll contributions to the pay-as-you-go system. Permitting stock market investments as well would allow individuals to take advantage of what until now have been greater returns on stocks than on bonds, though as I argue below, these differential returns on equities may not be as great in the future as they have been in the past.

However, it would cost social security more to administer a system of individual accounts than to administer the present system. Since the accounts would be separate from the social security trust fund, there would also need to be some gradual cuts in the growth of benefits over time to bring the trust fund into long-term actuarial balance. These could be done in a way that focuses on high-income individuals and leaves low-wage and disability benefits largely intact. I designed the combination of the returns from the individual accounts and the benefit cuts to leave overall future retirement payments roughly constant.

But mandatory add-on individual accounts did not prove highly popular, and there have been several attempts to ease the political pain. The National Commission on Retirement Policy suggested a similar approach, but with the individual accounts "carved out" of the present payroll tax. Advantages and disadvantages of this system are similar to those of the plan I recommended, with the significant exceptions that the National Commission's plan would not have increased saving now, and in the long run would have cut overall retirement benefits. 
In his 1999 budget message, the President also suggested an approach that might be more palatable politically. He proposed voluntary saving accounts (now called Retirement Saving Accounts) that would carry a tax subsidy and be matched. The voluntary accounts would be available only to lower-income workers, who now have the lowest levels of pension saving. But, at the same time, voluntary is voluntary. Only about one-quarter of all low-income households now use freely available tax-subsidized Individual Retirement Accounts, and only about 40 percent use 401(k) plans that carry a tax subsidy and are also matched by employers. Unlike mandatory accounts, this voluntary approach would not ensure that all underfunded workers looking at reductions in their retirement standard of living would choose to contribute to the new individual accounts. For the same reason, this and other voluntary measures might raise national saving relatively little.

In the same 1999 budget message, President Clinton also proposed two measures to deal with the actuarial problems of the social security trust fund. Rather than raising payroll taxes, he would have made transfers of general federal revenues to the social security trust fund. If these transfers were not made from new borrowing, they would effectively finance added benefit costs through higher federal taxes or lower government spending than would otherwise be the case. Provided that there were offsetting cuts in the general government budget, these transfers should raise national saving, just as would higher payroll taxes. At the same time, the same considerations suggest that there could be some added tax distortions.

Transferring general revenues would imply that, for the first time, revenues from outside normal trust fund sources would be used to finance social security benefit payments. There is nothing intrinsically wrong with broadening the tax base beyond the payroll tax, but there is a potential problem in breaching the trust fund limits. Until now the social security trust fund has been self-financing. The present value of all present and future benefit payments equals the value of existing stocks of assets plus the present value of present and future tax revenues. This long-run budget constraint has presumably limited benefit payments. If general revenue transfers were to be introduced, it might become much harder to limit these transfers in the future. This could be a backdoor way of putting the social security system on just the tax-and-spend treadmill that politicians are trying to avoid and that many other countries have not avoided.

The President also proposed to invest some of social security's assets directly in common stock index funds instead of government securities. This reinvestment plan raises several new issues. First, unlike the add-on individual accounts proposed above, this would be equity investment without underlying new saving. As such, it would represent only a transfer of wealth with the private sector, not a creation of new national wealth. Second, since the central fund, and not individuals, would own the equities, the direct government ownership of common stock might threaten normal business-government separations. Third, as with the individual accounts, one can ask whether future returns to equities will continue to exceed those on bonds. There is no doubt that stocks have outperformed bonds in the past, but at this point earnings-price ratios on stocks have been driven close to real interest rates on bonds, in the view of many financial experts providing inadequate compensation for the greater risk on stocks. In this sense, it may not make sense to extrapolate past differential returns on stocks. For whatever reason, the President later withdrew the equity reinvestment part of his approach.

In response to the President's plan, congressional Republicans produced one of their own. Instead of having the government make the investment in common stocks, the Republicans created small-scale individual accounts by diverting revenue from the normal payroll tax. The money would go into individual accounts, but with a twist. Individuals would choose how to invest the funds, with government constraints on the type of investments and even on the share that could be invested in equities. Returns from the funds would in effect be owned by social security. If the invested funds did not yield benefits as high as social security, individuals would be guaranteed their normal social security benefits, and the social security trust fund would keep all returns from the individual accounts. If the funds yielded more than social security, individuals would get their normal social security benefits and could keep the extra. If the stock investments do outperform government bonds, there could be enough saving in normal social security benefits that the actuarial soundness of the trust fund could be ensured. 
These quasi-private accounts also raise a number of issues. First, as with the other stock investment plans, will future differential returns on equities hold up? If not, the plan may not resolve the long-run actuarial problems of the social security trust fund. Second, if the social security trust fund is in effect guaranteeing the performance of individuals' investments, in the sense of paying at least the same benefits that individuals would have otherwise received, does it really make sense to allow the individuals to choose the investments? Even under the tight investment constraints, individuals may gamble, given their complete safety net. Third, as a political matter, if these individual accounts are described as individual accounts, would it in fact be possible for the government to take back all returns up to the normal benefit levels of social security? Such a "clawback," as it has become known, might be viewed as unwarranted government taxation. Very often, schemes such as this result in arrangements in which private investors get the gains and the government picks up the losses.

There are clear differences among these competing approaches, though not so clear that compromises seem out of the question. One central issue is that of equity investment: How profitable will it be in the future, as opposed to the past? Will it be profitable enough to account for the greater risk on stocks? And, if it is done, should it be done through individually owned accounts or through central fund investment? Individual accounts are more expensive to run, and they may at some point fray the political compromise underlying social security—a general program benefiting all. At the same time, they also avoid other political problems that may result from central fund equity investment, if the government becomes a huge, and perhaps the largest, stockholder for most American corporations.

Then there is the national saving issue, which I think is central. And here is a potential pitfall—the approaches with the most political popularity may also be those with the least effect on national saving. The least popular approach involves payroll tax increases to prefund benefits. The mandatory add-on individual accounts have also not proven very popular and also clearly involve new saving. Switching to voluntary individual accounts may be a reasonable political compromise, but it also involves much less new saving. Covering the actuarial deficit by general revenue financing should raise national saving, at least if the non-social security portion of the federal budget is suitably altered, but it may simultaneously weaken fiscal discipline. And it, too, has not proven popular. Carving the individual accounts out of existing payroll taxes may also represent a political compromise, but it also does not raise national saving.

\section{Conclusion}

Social security has been a huge success in the 20th century, arguably the largest and most popular social program the government has ever adopted. Its reach is now nearly universal, it has pulled millions of aged individuals out of poverty, and it forms a retirement safety net for virtually all Americans.

The history of social security in the 20th century has been one of program growth—of tax rates, benefit levels, and coverage levels. But times are changing. At this point the system is nearing maturity and is confronted with a new problem - the massive aging of the U.S. population. We could respond to this population aging, and attendant rise in payroll tax rates necessary to pay for future benefits, by further increases in payroll tax rates, as was the case throughout most of the 20th century. Or we could try some new approaches, such as add-on individual accounts, general revenue transfers, or various mechanisms for investing in equities. All of these can, in principle, pay for the presently scheduled level of future benefits and preserve the actuarial soundness of the social security trust fund. But only some of them imply new national saving, the high rates of return on this new saving, and new investments in American productivity. Our hardest job now is to find reform measures that really generate this new saving. 